\title{
EL OTRO Y LO MISMO: \\ Peripecias del cuerpo al filo del 2.000
}

Antonio SÁNCHEZ

Prof. de Filosofía en Enseñanza Secundaria

\section{Introducción cinematográfica}

Recuerdo ahora el siguiente escenario. El espacio de la vida se dispone secuencialmente en tres salas. La primera es la cocina, que semeja un gran bodegón flamenco, en una nave catedralicia, con mesas y alacenas repletas de viandas, calderos de cobre donde humean los guisos, tonos de claroscuro, ocres, tierras, verdes ensombrecidos. Un niño canta como un ángel caído implorando la piedad del Dios. En el espacio en el que se cuece la vida resuenan los ecos de esa edad limítrofe donde se dieron cita las viejas teologías y las filosofías de la nueva ciencia. Se adivina el modo cartesiano de una época que, sin dejar de creer en un hombre insuficiente y necesitado, empieza a soñar la posibilidad de la autonomía de la razón. La retina se puebla de caballeros que juegan a dados mientras discuten sobre la perfección del cosmos y trinchan un pomposo faisán. El jefe de la cocina, un hombre instruido, buen conocedor de su oficio, sabe que tiene el deber de alimentar un nuevo mundo.

De esta estancia se pasa a otra, al comedor de telas bermejas y lámparas de araña, de brocados dorados y ricas mesas donde brilla la plata. A los platos que degustan los comensales les ha dado nombre una revolución en Francia. Preside la escena, al fondo, un cuadro con gentiles ciudadanos de rostro satisfecho y banda al pecho. En los muebles Imperio, en los espejos, en los suntuosos ropajes, se proclama el triunfo de una idea que ya se extiende por los salones, por los palacios y por los teatros de ópera, una idea que atiza a los ejércitos para que éstos, a fuego y sangre, crucen Europa y dominen antiguas tierras. El dueño del local, el ladrón,

Éndoxa: Series Filosóficas, $n^{\circ} 4,1994$, UNED, Madrid:

Antonio Sánchez: El otro y lo mismo: peripecias del cuerpo al filo del 2000.

pp. 255-277. 
ataviado a la usanza de los viejos ciudadanos, apenas puede leer la carta del menú; groseramente habla sobre digestiones con sus secuaces, y de vez en cuando se atraganta con un bocado, derrama el vino que rebosa de su copa, o eructa. Él también es el dueño de la tercera estancia, allí donde todo va a parar, el cuarto de aseo, blanco y funcional como una sala de disección, siglo $X X$ de vuelos lunares y aséptica muerte de hospital. Los personajes de este sueño, del color de la sangre en el salón-comedor, mudan sus tonos en este espacio profiláctico, y se vuelven lechosos y puros, renovados.

Y así es el mundo que ha logrado dominar el ladrón, señor único de su territorio; la vida transcurre en este espacio clausurado y nada puede escapar del receptáculo que forman las tres estancias, porque la voz del ladrón, siempre excesiva, siempre brutal, no permite que haya más realidad que la que se exhibe en la carta o en las pintadas de los retretes. El mundo del ladrón se extiende desde la cara hasta las posaderas, y en su término da cobijo a un hombre moderno que ha conseguido por fin tomar tierra, tal y como pedían los revolucionarios hegelianos, y está agachado para defecar. Afuera, lejos del territorio, todo es oscuridad y confusión, y aúllan los perros.

¿O no? Un hombre lee mientras come, y su gesto no ha pasado inadvertido. El ladrón le recrimina este comportamiento, le lanza el libro al suelo, le recuerda las únicas lecturas permitidas, el único lenguaje tolerado. La mujer del ladrón ve en los ojos del hombre que lee una ventana abierta. Ella se cuela por la ventana y cae en sus brazos. Desde ese momento ambos desbaratan todos los usos de las estancias, porque se aman en los retretes y en las despensas, porque el hecho de estar en el salón y comer ya sólo es una excusa para mirarse y amarse. En todos los momentos cuentan con la complicidad del cocinero, que sigue siendo fiel a su viejo cometido de conservar la vida.

Sin embargo, los amantes deben huir, porque el ladrón, ojo que todo lo ve, no tarda en darse cuenta de que es burlado. Los amantes, sin el más ligero equipaje sobre sus cuerpos, en un viaje 
de retorno hacia una desnudez ancestral, tienen que recorrer el espacio de las sombras en el compartimento frigorífico de un camión donde cuelgan cuartos de animales comidos por los gusanos. Al final del camino hombre y mujer se esconden en la biblioteca.

Pero el ladrón no va a tardar en descubrir el refugio de los amantes; sorprende solo al lector y le asesina obligándole a engullir páginas de libros, por la boca, por las narices, por los oídos. Y no podría ser de otra manera, porque el castigo que se merece aquél que se atreve a escapar de la rutina del cuerpo no es otro más que el de volver a ella, reintegrarse al ciclo comiéndose aquel ser huidizo que se ha atrevido a desafiar el orden de las estancias. El lector muere tragándose la palabra. Recuerdo en el sueño su rostro congestionado y su cuerpo sangrante, y la forma terrible en que la mujer se acurruca junto a su cadáver y le vela esa noche.

Las imágenes se suceden. El cortejo fúnebre entra en el salóncomedor. Sobre una inmensa bandeja yace el cuerpo cocinado del lector. A petición de la mujer, el cocinero ha accedido a preparar el macabro guiso. La comitiva obliga al ladrón a sentarse a una mesa; la mujer corta el pene del cadáver y se lo ofrece al ladrón. Éste se asquea, vomita, pero mastica y traga. Sabemos que le acabaría gustando, que acabaría comiéndose el cuerpo entero. La mujer toma un revólver y le descerraja un tiro.

Tremenda fantasía ésta del conflicto entre las estancias del cuerpo y los lugares de la palabra. Y tremenda también la forma en que el autor de este sueño ${ }^{1}$ nos hace imaginar cómo tal conflicto se concreta en el crepúsculo del siglo XX. Detengámonos en semejante escenario y en los personajes de la fábula.

1. Esta secuencia de imágenes constituye una recreación de "El cocinero, el ladrón, su mujer y su amante", película de Peter Greenaway de la que nos hemos permitido extraer esta interpretación lógica, sin duda inaceptable para aquéllos que no toleran la transcripción del lenguaje cinematográfico al lenguaje de la reflexión. De cualquier modc, confiamos en: qui el lecto: será condescendiente, y no exigirá más verdad de la que los sueños pueden ofrecer. 
El espacio que se nos describe, como imagen del mundo, simboliza con sus tres estancias los tres momentos del proceso histórico que desemboca en la época contemporánea, esto es, el período barroco que inaugura la reflexión sobre la conciencia moderna, el momento triunfal de la autonomía del sujeto en los siglos ilustrados y racionalistas y, por último, la modernidad funcional y cibernética. Las tres estancias también representan un cuerpo cerrado en sí mismo, de supuesta autosuficiencia, la constitución de un habitáculo sin ventanas que no permite más movimiento que el constante proceso de alimentación. En este sentido, el habitante de las estancias, el hombre contemporáneo, como una mónada leibniziana, queda encarcelado en su piel, sin salida posible al exterior, sin posibilidad ninguna de mutación. Prisionero en su cuerpo, no tiene más remedio que estar de continuo pendiente de sus procesos digestivos o excretores. El hombre ha acabado siendo lo que come. Si logra enseñorearse de ese espacio, si logra ser el ladrón, aceptará con gusto semejante reclusión, y no permitirá que nadie ponga en peligro la seguridad del lugar que habita. Por supuesto, muchas calamidades podrían acarrear la ruina de la tranquilidad que en ese claustro maternal se disfruta. En otra de sus películas, «El vientre del arquitecto», Greenaway mostraba a un hombre obsesionado con su vientre, un hombre que empieza a estar demasiado pendiente de su ombligo y de los ombligos que ve en sus paseos por Roma. Su preocupación por el interior del cuerpo discurre paralela a un interés indiscreto por las habitaciones cerradas; le sorprendemos mirando por el ojo de la cerradura, espiando a su mujer, descubriendo que ella tiene un amante. La ambivalencia del cuerpo se le hace patente cuando se entera de que el vientre de su mujer ha concebido un hijo, pero que en el suyo ha crecido un cáncer. Desde ese momento el arquitecto, el señor del espacio, mudo testigo del desastre, pierde el dominio de su emplazamiento y comienza a quedarse solo en la muerte. Observando su inútil batalla por recuperar un territorio de inminente ruina llegamos a comprender la ambigüedad del cuerpo, la inconstancia de la seguridad que se asienta 
sobre él, inconstancia que es también del espacio y del tiempo, de la arquitectura de la ciudad, del cuerpo otro. De forma trágica expresa el cineasta que el cuerpo donde se genera la vida también esconde la muerte.

Sin embargo, el peligro que desasosiega nuestro sueño de estancias no es el descubrimiento de la muerte oculta, sino la apertura del cuerpo hacia el exterior, la extensión más allá de los dominios gracias al amor del Otro, un amor que es huida fuera de si, y que se concreta en el acto de lectura y en la mirada de los amantes. $Y$ ha sido éste un tema de reflexión constante en la filosofía fenomenológica y existencialista del siglo XX, de tal modo que el asunto de la vivencia del cuerpo no deja de estar presente en las obras de Jean Paul Sartre, de Merleau-Ponty o de Albert Camus, por citar algunos autores de estas corrientes. Atendamos en primer lugar al planteamiento de Camus.

Teoría del cuerpo insatisfecho (Camus)

Pero todo el mundo sabe que la vida no vale la pena de ser vivida El extranjero, Albert Camus

En el Prólogo que Mario Vargas Llosa escribiera para introducir la lectura de El extranjero de Camus², se nos sugiere que podría ser Merseault, el personaje ajeno a las normas y a los valores que protagoniza la novela, una premonición de un prototipo contemporáneo. Y la afirmación sin duda nos resulta sorprendente, pues no parecen los hombres de los tiempos que corren proclives a la lectura de los escritores existencialistas, y mucho menos a identificarse con los tipos humanos que tales textos dibujaron. ¿Qué es lo que aprecia Vargas Llosa en Merseault para emitir este juicio? «A los lectores de hoy, sobre todo a los de esta Europa tanto más próspera, confiada y hedonista que aquella, miedosa, atolondrada y cataclísmica, en la que El extranjero vio la luz, el solitario protagonista de esta ficción puede atraerlos por lo que hay en él

\footnotetext{
2 CAMUS, Albert, El extranjero, Barcelona, 1988. El Prólogo lleva por título: «El extranjero debe morir».
} 
de epicúreo, de ser contento de su cuerpo y orgulloso de sus sentidos, que asume sus deseos y apetitos elementales sin rubor $\mathrm{ni}$ patetismo, como un derecho natural. De todo el fuego de artificio que fue la 'revolución de mayo' de 1968, ese gran alboroto de jóvenes insatisfechos con su sociedad y su tiempo, vagamente idealista, generosos y confusos, eso es lo que parece haber quedado como logro: los deseos humanos salen de los escondites adonde habían sido confinados por el cuerpo social y comienzan a adquirir carta de ciudadanía ${ }^{3}$.

En cierto sentido tiene razón Vargas Llosa; Merseault no parece abandonar a lo largo de la novela el terreno de la sensación y de los sentimientos más egoístas. Las cosas y el conjunto de los acontecimientos quedan reducidos en su discurso a estados de ánimo, percepciones, deseos, situaciones de dicha o de desagrado. El mundo de Merseault comienza y termina en su propio cuerpo. Esto, que ocurre en todos los momentos de la narración, puede llegar a exasperar al lector que esperase una reacción distinta del protagonista. Recordemos algunos pasajes. Velando el cuerpo de su madre el extranjero atiende al gusto del café con leche, al aroma de la noche y de las flores, al resplandor de la luz contra las paredes blancas; estudia con detenimiento, en un duermevela, los gestos de los ancianos que le acompañan en el velatorio. Ya camino del cementerio, está atento a los colores del cielo, al sol, al olor del cuero y del estiércol del coche, a la pesadez que le produce la fatiga de una noche de mal dormir. No hay ni una frase que manifieste duelo, y por eso se le va a juzgar. Tampoco muestra Merseault más interés por los sentimientos comunes en su idilio con María, o cuando asiste a las trifulcas de Raimundo, el vecino que explota y maltrata a su amante. En el momento cumbre de la narración, en ese momento en el que Merseault dispara sobre el árabe, estamos sintiendo el calor del sol, el sudor que corre por la frente y nubla la vista, los ojos doloridos de fuego y sal. El

3 Ibid., pg. 15. 
extranjero sólo podrá justificar su acción diciendo que en el momento del crimen hacía calor.

En efecto, el protagonista del relato se comporta como un desalmado, lo que no deja de ser evidente. Sin embargo, debemos atender a la trampa que encierra el libro, al secreto que le da nombre. Merseault, el canalla, es un «extraño», un «extranjero»; su rareza consiste en que, a diferencia de los otros personajes, tiene una indómita conciencia de la nada. No se diferencia de los demás por su egoísmo sensitivo, por estar recluido en su cuerpo y en sus pasiones -algo que en definitiva también les ocurre a los otrossino porque lo sabe y sabe también la vacuidad de tal reclusión. Merseault no tiene más remedio que vivir en su cuerpo, pero no se llega a creer su cuerpo. Esto es lo que le hace fundamentalmente antisocial, el no fingir, el no hacer cínicas concesiones que, según el carácter trazado por Camus en el personaje de Merseault, no vendrían más que a ocultar su conciencia del sinsentido, su seguridad de la sinrazón profunda de la existencia. La pantomima de la razón social se hace patente en el pasaje del juicio, pues allí se muestra que la locura de los hombres, para dar sentido a la acción, es capaz de utilizar los más mínimos e insignificantes detalles con el fin de tejer un argumento que muestre la bestialidad del asesino. Todo vale con tal de que la mascarada resulte convincente. Merseault asiste impávido a la charla de esos juristas que asegurar conocer su alma, y lo hace desde su continua lejanía, alabando incluso los discursos que preparan su muerte por la corrección y verosimilitud que el fiscal acusador es capaz de conferirles. Merseault asiste a su propio juicio como si fuera de otro; no está dispuesto a reconocerse en aquel ser que han urdido. Incluso cuando el abogado defensor, haciendo alarde de una estúpida oratoria, representa el papel del asesino y le roba su nombre, el extranjero sale pronto de su asombro y se da cuenta de que es un hecho sin importancia, porque él ya no está en la sala de audiencias. Está pendiente de los ruidos de la calle, del declinar de la tarde, del cansancio... "Al final, sólo recuerdo que desde la calle y a través de las salas y de los estrados, mientras el abogado 
seguía hablando, oí sonar la corneta de un vendedor de helados. Fui asaltado por los recuerdos de una vida que ya no me pertenecía más, pero en la que había encontrado las más pobres y las más firmes de mis alegrías: los olores de verano, el barrio que amaba, un cierto cielo de la tarde, la risa y los vestidos de María. Me subió entonces a la garganta toda la inutilidad de lo que estaba haciendo en ese lugar, y no tuve sino una urgencia: que terminaran cuanto antes para volver a la celda a dormir ${ }^{4}$.

$\mathrm{La}$ experiencia del placer corporal es tan fugaz, tan poco satisfactoria, que no llega nunca a justificar el más mínimo esfuerzo vital. No se puede hablar de epicureísmo en el caso de Merseault. Éste no emprende su acción porque persiga la consecución de un placer o de un bienestar. Merseault no actúa; simplemente, le ocurren cosas, dulces o dolorosas, amigables o canallas. Y siempre queda esa sensación de insuficiencia, ese vacío en la boca del estómago, y el hastío al contemplar los trabajos que realizan los otros para poder creer en la verdad de sus acciones. Merseault no muere por su maldad, sino por la seguridad con que la admite, pues en este teatro del mundo lo peor que le puede ocurrir al villano es parecerlo. La villanía de Merseault radica, pues, en la conciencia que tiene de su ser absurdo. $Y$ el ser absurdo, habitante de un mundo absurdo, cuando es consciente de ello se sabe inútil, sin importancia: «Todo lo que hace trabajar y agitarse al hombre utiliza la esperanza. El único pensamiento que no es mentiroso es, por lo tanto, un pensamiento estéril. En el mundo absurdo, el valor de una noción o de una vida se mide por su infecundidad ${ }^{5}$.

¿Qué pretende entonces Camus? ¿Mostrar en el personaje de Merseault la monstruosidad de un ser humano que por un ilimitado ejercicio de su libertad no reconoce ningún tipo de condición social y que, por tal razón, no puede dejar de ser insolidario y de desarrollar una sensualidad animal desprovista de

\footnotetext{
4 Ibid., pg. 134.

${ }^{5}$ CAMUS, Albert, El mito de Sísifo, Madrid, Alianza Editorial, 1981, pg. 94.
} 
los más básicos valores espirituales? Si así fuera, como quiere Vargas Llosa, en el libro de Camus volveríamos a descubrir un precepto ya harto conocido, aquél que nos incita a evitar el individualismo feroz y a desear los seguros beneficios de la vida social, aunque a sabiendas de que para su disfrute no nos queda más remedio que aceptar también los inconvenientes y las limitaciones que la convivencia exige. $Y$ con esta sentencia estaríamos planteando de nuevo una de las soluciones de la antigua disputa griega sobre la naturaleza del Estado, y no habriamos dejado nunca de discutir con los sofistas. ¿Sólo nos dice la novela de Camus este principio de la ventaja de la sociabilidad, en su difusa abstracción de todos admitido, o es capaz de expresarnos la forma en que se concreta el pacto social a la espera de la guerra? Merseault es un canalla, en un mundo de canallas que no están dispuestos a aceptar al que no participe en el juego. $Y$ el juego consiste en silenciar la pesadumbre que auguran los tiempos. Mascándose ya la exaltación de la autosuficiencia que van a vocear los totalitarismos fascistas -la perfección del ario- observamos que el individuo más peligroso para este ideario será aquél que, asumiendo con plena conciencia el modelo de hombre imperante, ponga de manifiesto la inviabilidad de un proyecto social gestado en tales condiciones. Merseault ha de ser suprimido porque su falta de fingimiento está revelando lo que se está intentando ocultar, esto es, que no hay diferencia ética entre el extranjero y los que lo condenan, que se está gestando una ferocidad que arrasará Europa y que se soportará en un ingenuo y miserable ideal social basado en la plenitud del individuo. $Y$ ese proyecto de hombres satisfechos de sí mismos, que niegan al otro hasta suprimirle, encierra en sus entrañas el germen del suicidio social. El grupo, bajo el amparo de sus leyes, va a matar judíos, gitanos, rusos, polacos o franceses con la misma indiferencia que Merseault disparará contra el árabe, pero sin la conciencia que este personaje tiene del absurdo; todo lo contrario, ellos lo harán con la fingida y común seguridad del acto justo. Merseault no se apiada, pero tampoco le busca justificación ninguna a su acción; los otros 
tejerán un enorme universo de significaciones con el que podrán explicarse la necesidad del crimen. No estamos en el mayo del 68, según apuntaba Vargas Llosa, sino en el bombardeo de Guernica. Merseault, como Calígula, dice lo que nadie quiere oír: que en esa pretendida suficiencia, que en ese aire de plenitud sensual, se esconde la muerte. Por eso es necesario matarle. Por eso Vargas Llosa, que siempre ha dado muestras de poseer una confianza en lo social digna de un santo -o sea, esa confianza de otro mundo que tantos cadáveres ha bendecido-, tampoco le llorará. Y Merseault se sentirá más acompañado: «Para que todo sea consumado, para que me sienta menos solo, me quedaba esperar que el día de mi ejecución haya muchos espectadores y que me reciban con gritos de odio" ${ }^{6}$.

Teoría del cuerpo insuficiente (Sartre)

Existo para mi como conocido por otro a título de cuerpo. El Ser y la Nada, Jean-Paul Sartre

En el pensamiento de Sartre observamos un planteamiento que difiere en gran medida del que hemos leido en la novela de Camus, y que nos muestra otra de las formas en las que el hombre del siglo $X X$ se instala en su cuerpo. Constituido como alteridad radical, necesariamente puesto más allá de sí, el hombre de Sartre sólo puede llegar a tomar noticia de su existencia en la mirada del otro. Los otros son condición necesaria de la constitución de la existencia individual, existencia que se revela, entre otros modos, como corporeidad. Esta condición esencial de la intersubjetividad queda claramente expresada en el discurso sobre el humanismo que Sartre publica en 1946. La guerra ha terminado y el filósofo francés afirma: «No hay otro universo que este universo humano, el universo de la subjetividad humana. Esta unión de trascendencia como constitutiva del hombre -no en el sentido en que Dios es

\footnotetext{
${ }^{6}$ CAMUS, A., El extranjero, op. cit., pg. 154.
} 
trascendente, sino en el sentido de rebasamiento- y de la subjetividad en el sentido de que el hombre no está encerrado en sí mismo sino presente siempre en un universo humano, es lo que llamamos humanismo existencialista» ${ }^{7}$.

Cercanas en su publicación a El Ser y la Nada (1943), ponen de manifiesto estas líneas una valoración de la intersubjetividad que parece contradecir el pesimismo del que Sartre habia hecho gala en su anterior obra. Sin embargo, la presunta contradicción no tiene por qué sorprendernos, pues en el pensamiento sartriano se van a dar cita dos consideraciones enfrentadas que, según el rigor del análisis, no dejan de ser igualmente justificables: la constitución social del sujeto humano y el fracaso continuo del proyecto social. El hombre está condenado a ser para los otros, y es ésta la maldición en la que se cifra el infierno en vida. Pero no acaba aquí el suplicio, pues la condena nunca deja de ser necesaria en cuanto constituye una dimensión esencial del mismo ser individual, de la misma libertad. El hombre sartriano se deshace, se suprime, al mismo tiempo que se realiza. Más que de un hombre absurdo cabría hablar de un hombre imposible, y si el mito que preside el pensamiento de Camus es el del inútil trabajo de Sísifo, tras leer a Sartre no podemos menos de imaginar el tejido de Penélope pero en versión macabra: Penélope teje con la hebra que se va soltando al otro extremo de la labor. Yo sólo soy en la medida en que es el otro, pero en la medida en que es el otro, yo no puedo ser. La condición que afirma es la condición que niega. Danzando en la cuerda floja de la paradoja, el sujeto sartriano se afirma como un ser que está continuamente escapando de sí mismo, en un más allá constitutivo que es, al unísono, también su principio disgregador.

En este momento de posguerra se hace necesario abandonar el cuerpo de los sentidos en que se instalaba el personaje de Merseault porque ese cuerpo se ha vuelto tedioso, inhabitable. La sensación crucial, compartida con Heidegger, es la náusea: la vivencia del cuerpo como la de un ser que se agita de forma estéril

7 SARTRE, J. P., El existencialismo es un humanismo, Buenos Aires, ed. 80, 1981. 
en un vacio absoluto, que simplemente está ahí, desparramado entre las demás cosas, en la ausencia total de necesidad, desprovisto de todo sentido, dándose de forma gratuita, sin razón, simplemente existiendo. Como si se tratase de un tejido canceroso, la existencia no tiene más ley que la de la proliferación indefinida; se multiplica sin ningún fin, por la mera potencia de un impulso que tiende, como en una pesadilla, a crecer y a agigantarse. En esta situación, el cuerpo se solidifica, se descubre siendo otra cosa entre las cosas, igualmente pesado y espeso. Es un momento en el que no se puede permanecer; la conciencia siente horror al hundirse en el sentimiento espantoso del vacío. La conciencia del absurdo es intolerable. No podemos imaginar a Sísifo feliz.

Pero el hombre sartriano no pretende solazarse en la dejadez, no quiere agotarse en ese cuerpo que es mera relación sensitiva, instinto de proliferación y supervivencia, fenómeno natural. La corporeidad de Sartre intentará superar las barreras de la piel y extenderse en la relación intersubjetiva. Pero no lo logrará. Porque entre el otro, que me petrifica con su mirada, y mi yo, negación constante de lo ya sido, de cualquier ser definitivo, no puede haber más que guerra. En mi ser para el otro me constituyo como objeto; la mirada del otro dispone una disgregación de mi propio universo y una reorganización de la cosas en torno a un punto que yo no puedo alcanzar, y con respecto al cual me coloco cayendo de pleno en la facticidad, como cualquier otra cosa del mundo. Mi ser sujeto se desvanece y emigra hacia el otro que me mira, para quedar allí solidificado y enajenado, negado como posibilidad de continua negación, esto es, desprovisto de libertad. La mirada del otro representa una amenaza para mi libertad, porque en ella se me afirma, se me dice quien soy, cuando el yo sujeto justamente se constituye en la negación de sus formas de ser: no siendo lo sido y siendo lo que todavía no es. "Mi cuerpo es ahí no sólo como el punto de vista que soy, sino también como un punto de vista 
sobre el cual se adoptan actualmente puntos de vista que yo no podré alcanzar jamás; me escapa por todas partes -dice Sartre».

En la medida en que mi mirada opera idéntico proceso de definición del otro sujeto, y amenaza de igual modo su libertad, la relación de las miradas será la de dos existencias que se enfrentan para destruirse, la de dos miradas que en su mirarse se congelan. ¿Qué lejos este mirar áspero y desolador de aquél otro de Machado, en el que los ojos se hacen compañía! «El ojo que ves/ no es ojo porque tú lo veas/ es ojo porque te ve».

Pero, ¿acaso no hay que temer la mirada de un otro que ha puesto de manifiesto, de nuevo, su espíritu más feroz, su ser de lobo? A puerta cerrada $a^{9}$ Sartre reúne a un traidor, a una lesbiana y a un infanticida, en un cónclave espantoso y sin escapatoria, que condena a cada uno de ellos a entregar su vida en manos ajenas. La situación resulta intolerable y además nada se puede hacer para evitarla: las miradas vigilan, y los personajes son continuamente espiados, interrogados, forzados a dar cuenta de la propia existencia, que individualmente no pueden dejar de considerar indefinida y abierta, pero que constantemente se colapsa en el discurso de los demás. Y resulta que el tormento no radica en la condición canalla de los recluidos; radica en la misma convivencia forzada e infernal que les obliga a estar juntos. Idéntica amargura

\footnotetext{
8 SARTRE, J. P., El Ser y la Nada, Madrid, Aguilar, 1982, pg. 522.

9 A puerta cerradz (Huis-clos), obra de teatro estrenada el año 1944. Según Suzanne LILAR (A propos de Sartre et de l'amour, Paris, Grasset, 1967), todos los detalles que caracterizan el planteamiento de Sartre sobre la relación intersubjetiva (el rechazo que muestra a la convivencia, al sexo, a lo femenino, la obsesiva consideración del cuerpo carnal como una cosa turbia y viscosa, su profundo pesimismo en lo que atañe a la bondad del (tro), son consecuencia de los fracasos vividos por Sartre en la infancia: la muerte de su padre y su sustitución por un detestado abuelo, las lágrimas de su madre por la fealdad del hijo, su propia conciencia de esta fealdad, el fracaso de su educación, etc... Sin embargo, nosotros pensamos que al análisis de Sartre no le resta interés su posible relación con la experiencia vitai; todo lo contrario, esa experiencia viene a enriquecer un discurso cuyo planteamiento afectivo no es exclusivo de Sartre, pues podemos encontrar numerosas similitudes entre la postura sartriana y la visión kafkiana del cuerpo como mutación monstruosa, o descubrir parecídos con el tratamiento de la incomunicación que hace el "teatro del absurdo", o que revelan los desquiciados personajes de Elias Canetti en Auto de fe.
} 
se produciria, apunta Sartre, si se hubiese escogido un mariscal de Francia, una monja carmelita, y una honrada madre de familia.

Y aún así, preciso de la mirada del otro para tomar noticia de mí mismo. En Le Sursis (1945) Daniel escribe a Mateo: «Durante un instante tú has sido el mediador entre mí y yo mismo, el más precioso del mundo a mis ojos, ya que este ser denso y sólido que yo era, que yo quería ser, tú lo percibías tan simplemente, tan comúnmente como yo te percibía a ti... Comprendí entonces que uno no podía alcanzarse más que por el juicio de otro, por el odio de otro... No sé qué nombre darás, hoy dia, a nuestras relaciones. No es amistad, ni odio a secas: digamos que hay un cadáver entre nosotros: mi cadáver ${ }^{10}$. Ésta es la circularidad de la que no puede escapar un cuerpo que sólo se conoce en cuanto reflejo en los demás, pero que al mismo tiempo se sabe irremediablemente traicionado. Por una parte, el fundado deseo de encuentro; por otra, la realidad del conflicto y del fracaso. Si el proyecto es alcanzar al otro en su ser un otro-yo, resulta que estoy atrapado en un laberinto del que no puedo escapar. Porque el otro me huye cuando quiero poseerlo, y me posee cuando quiero huirlo. $Y$ son ambos deseos constitutivos, querencias que no puedo evitar sin en el acto suprimirme a mí mismo.

Supongamos que se pretende el amor. Se trata, según Sartre, de que cada amante se identifique con la libertad del otro, de una apropiación peculiar en la que los amantes se hurtan a su facticidad y al simple deseo de posesión física, para convertirse en objetos de libre elección, lazos aceptados. El ideal del amor consistiría en un querer libre a través de la fascinación, mediante el sortilegio que opera la palabra. «El surgimiento del otro frente a mí como mirada hace surgir el lenguaje como condición de mi ser ${ }^{11}$. Pero la seducción del lenguaje todavía no es suficiente

${ }^{10}$ El tema del reconocimiento como reflejo en el Otro vuelve a encontrarse en Las moscas, en ese Egisto que no existe más que como imagen que los otros tienen de él. Como el traje del rey en el cuento de Hans $C$. Andersen.

${ }^{11}$ SARTRE, J. P., El Ser y la Nada, Madrid, Aguilar, pg. 550-551. 
para generar la recíproca relación del amor; porque lo único que logra es declarar al otro como objeto precioso de poseer, sin conseguir ese movimiento de él hacia mí que es necesario para que no sólo sea un ser amado, sino también un amante. «El amor no puede nacer en el ser amado, pues, sino en cuanto éste experimenta su propia alienación y fuga hacia el otro» ${ }^{12}$.

Sin embargo, toda tentativa es inútil; el amor, ontológicamente, está destinado al fracaso. Y de tres formas se muestra su imposibilidad. En primer lugar, porque el amor es esencialmente el proyecto de ser amado por el otro, de tal forma que cuando esto ocurre, y el otro me ama, descubro que el sujeto en el que me pretendía fundamentar tiene tan en peligro su ser como yo. Busco la seguridad en un otro que a su vez, inseguro, pretende apoyarse en mí. $Y$ con esto se crea un estúpido juego de escondite cuyas reglas obligan a que el perseguidor sea al mismo tiempo el perseguido, como en esas secuencias chaplinianas en las que Charlot y su antagonista giran alrededor de un tronco de árbol sin llegar a verse el uno al otro. Con lo cual, cuando se me ama, en lugar de alcanzar la trascendencia que buscaba, sólo logro que se me vuelva a plantear la misma dificultad que creía haber resuelto. "Cuanto más se me ama, más pierdo mi ser, pues soy devuelto a mis propias responsabilidades, a mi propio poder ser ${ }^{13}$. En segundo lugar, en el amor estoy a merced de una simple fascinación, que en cualquier momento puede cesar y hacer que el otro aparezca como un mero utensilio para mis fines, como un mero objeto. Así, el otro siempre está en trance de desaparecer de mi proyecto y arrastrarme con él, pues yo me pierdo al perder su reflejo. Una última dificultad tienen que afrontar los amantes; en el momento en que son mirados por un tercero, cualquiera que fuere, experimentan sobre si toda la fatalidad de la mirada objetivadora e infernal del otro. Su unión, por fuerte que sea, no puede eludir el castigo al que se somete el ser social: «En realidad,

\footnotetext{
12 Ibid., pg. 552.

13 Ibid., pg. 555.
} 
aun si nadie nos ve, existimos para todas las conciencias y tenemos conciencia de existir para todas: resulta de ello que el amor como modo fundamental de ser-para-otro tiene en su ser-para-otro la raíz de su destrucción ${ }^{14}$.

No hay salida en este enredo del amor. Si me niego a seguir defendiendo mi subjetividad, con la pretensión de facilitarle al otro el acceso a mi ser convertido éste en objeto, caigo en la desesperación y en el error del masoquismo, de tal manera que me creo poder captar mi yo-objeto tal como es para el otro, asunto de por sí imposible. Puedo también, en el caso contrario, buscar la pelea, esto es, puedo intentar apropiarme la libertad del otro mediante la mirada: inútil, pues la libertad que pretendo se desmorona y aniquila en cuanto la miro.

Otra posibilidad de relación con el otro, perdida ya la esperanza del amor, podría ser la apropiación total de su cuerpo mediante la caricia, en el contacto carnal. Pero al acariciar no hago otra cosa que acariciar mi propia piel. No salgo de mí. La última ilusión se desvanece al igual que al personaje de Camus se le escapa el recuerdo de María cuando su piel se aparta de ella. Y la decepción consiguiente, el fracaso de mi encuentro con un otro cuya libertad respeto, me empujará hacia modos de relación más posesivos, menos recíprocos, aquellos en los que intentaré hacerme dueño del cuerpo ajeno. Siéndome patente la imposibilidad del amor, parece que no me queda -según Sartre- otra opción que aceptar el papel de ladrón. Por supuesto, cuanto más convierta al otro en objeto, más me alejaré de él, más distante me será su libertad. No voy a tener más remedio que tratarle como instrumento de mis deseos, de mi violencia, de mi ansia, de mi odio. Puedo negarle la mirada, mostrarme al otro en la indiferencia, actuar como si estuviera solo en el mundo, sentir a los demás de la misma forma que siento las cosas: «...rozo 'a la gente' como rozo paredes, los evito como evito obstáculos, su libertad-objeto no es para mí sino su 'coeficiente de

${ }^{14}$ Ibid., pg. 555. 
adversidad'; ni imagino siquiera que pueden mirarme» ${ }^{15}$. En cuanto puedo obrar de esta forma y conozco el arte de actuar valiéndome de los otros, ya me es sencillo utilizarles, pues se han vuelto simples títeres en mis manos. Es más, ocurre en ocasiones que algunos dedican toda su vida a profundizar en este arte de la manipulación, sin haber llegado nunca a sospechar lo que realmente puede ofrecer el Otro -la propia conciencia de sí-, y sin darse cuenta de que la indiferencia no llega nunca a anular del todo la mirada ajena, que ésta permanece sobre el que se evade de manera tanto más peligrosa, porque está cometiendo el error de creerse que por dejar de mirar ha conseguido también dejar de ser mirado. Yo mismo he afianzado los barrotes de mi encierro: «soy poseído sin poder volverme hacia el que me posee" ${ }^{16}$.

Insistiendo en la posesión del Otro, el deseo se hace cuerpo y me abalanzo hacia su carne, con la confianza de que en tal apropiación se me revelará también mi propia carnalidad. Habiendo renunciado ya a tomar contacto con la libertad del otro, me creo capaz de alcanzar su ser corporal instigado por el deseo sexual, pero no hago sino caer en una facticidad que anula mi conciencia y que sólo viene a ofrecerme al otro como simple objeto de mi deseo, instrumento en medio del mundo que capto a partir de su situación. "Nuevamente me encuentro, o poco menos, en la situación de que justamente intentaba salir por el deseo; es decir, trato de utilizar el objeto-Otro para pedirle cuentas de su trascendencia y, precisamente porque es integramente objeto, me escapa con su trascendencia integra. Hasta he perdido nuevamente la comprensión neta de lo que busco, y, sin embargo, estoy comprometido en la búsqueda..; soy como un durmiente que, al despertar, se encuentra con las manos crispadas sobre el borde del lecho sin recordar la pesadilla que ha provocado su gesto ${ }^{17}$.

\footnotetext{
15 Ibid., pg. 560 .

16 Ibid., pg. 562.

17 lbid., pg. 585-586.
} 
Ante el fracaso de la relación sexual todavía puedo extremar más mi deseo de apropiación del cuerpo del otro, y llegar al límite del sadismo, que tiene como objetivo la brutal posesión de la facticidad ajena sin arriesgar en lo más mínimo la propia libertad. Mientras en el deseo el sujeto que busca la relación ha de aventurarse a poner en juego su propia carne, pues es a través de ella como podrá poner de manifiesto la carne del otro, en el sadismo ya no hay mediación de la persona. Se trata de apropiarse del Otro inmediatamente, por la fuerza, mediante el instrumento que provoca dolor. "Quiere la no-reciprocidad de las relaciones sexuales; goza de ser potencia apropiadora y libre frente a una libertad cautivada por la carne ${ }^{18}$.

Con esto, el cuerpo otro abandona su situación y se convierte en algo obsceno, pues se presenta como una brusca aparición desnuda, gratuita, absurda, en carne viva, frente a la que el sádico no puede responder con el deseo, porque no tiene intención ninguna de exponer su propio cuerpo. Como dice Sartre, el cuerpo obsceno está de más. Y lo que pretende el sádico al someter el cuerpo del Otro a sus caprichos no es otra cosa, en definitiva, más que someter también la libertad del Otro: le obligará a pedir perdón, a creerse continuamente culpable, a que acepte el castigo, a humillarse, a poner sus decisiones y su voluntad en manos ajenas $^{19}$. $Y$ con todo y esto, no logrará ni siquiera su mezquino propósito de adueñarse del Otro poseyendo su carne: «...cuando la encarnación está conclusa, cuando tengo efectivamente frente a mí un cuerpo palpitante, ya no sé cómo utilizar esa carne: ningún

\footnotetext{
18 Ibid., pg. 587.

19 Recordemos, por ejemplo, cómo en la Historia de O la protagonista es regalada por su propio amante a un amigo. La plenitud de la relación consistirá en aceptar, por encima del amor, esta entrega, esta conversión en mero objeto de intercambio. "O" será más apreciada cuanto más inerte se muestre, cuanto menos voluntad propia sea capaz de demostrar. «O» será perfecta en el momento en el que todo la dé igual, cuando reconozca, con deleite, que su subjetividad ha desaparecido: «Pero ni aun utilizándola de este modo y tomándola como modelo u objeto de demostración, nadie le dirigió la palabra ni una sola vez. ¿Era acaso de piedra o de cera, o una criatura de otro mundo, o creían que sería inútil hablarle, o tal vez no se atrevían?" (REAGE, P., Historia de O, Barcelona, Ediciones 1984).
} 
objetivo podría serle asignado ya, pues precisamente he hecho aparecer su absoluta contingencia. Ella es ahi, y es ahí para nada ${ }^{20}$. La libertad del Otro, incluso doblegándose a la tortura del sádico y consintiendo, permanece allá fuera, irreductible. El poder de la mirada de la víctima sobre sus verdugos se vuelve insoportable; la burla de San Lorenzo ('dadme la vuelta, que ya estoy tostado por este lado') convierte cualquier esfuerzo del verdugo en trabajo inútil y vano. El hombre otra vez, tras las cámaras de gas nuevamente sometido a una colosal tarea de defenestración, en Chile, en Vietnam, en Argelia, en Corea, en Angola, en las calles de Pekín, en Palestina, en Sudáfrica, en la U.R.S.S., en los ghettos de New York o Lousiana, en el Kurdistán, en las cárceles franquistas, demuestra a sus asesinos que no hay forma de suprimir una mirada. Que esta persiste más allá del cuerpo, en una lejana memoria. Y ya no queda más que odiar al Otro; debo destruir al Otro para suprimir con ello la trascendencia que él representa. No me basta con adueñarme de la libertad otra, porque me he dado cuenta de que no puedo hacerlo. He de acabar con el problema del Otro por la vía más rápida. He de matarlo. Y con las manos en sangre, con la desesperación del que ha acabado con el objeto que anhelaba por la imposibilidad de acceder a él, me veo obligado a reconocer que con la muerte del Otro no he logrado suprimir mis carencias. El Otro se ha llevado a la tumba irremediablemente la clave de mi propio ser. $\mathrm{Al}$ cabo, estoy obligado a habitar un círculo terrible, porque en ese momento de la muerte del Otro vuelvo a desear que exista, y emprendo idéntico camino hacia ninguna parte. «El odio no permite salir del círculo. Representa, simplemente, la última tentativa, no queda al para-sí sino regresar al círculo y dejarse zarandear indefinidamente entre ambas actitudes fundamentales" $"$. Dar tumbos entre el amor y el odio. En La mujer de al lado Truffaut mostraba las tribulaciones de dos personajes incapaces de vivir juntos, incapaces de permane-

\footnotetext{
${ }^{20}$ SARTRE, J. P., El Ser y la Nada, pg. 534.

21 Ibid., pg. 605.
} 
cer separados. En las últimas escenas la cámara enfocaba una lapidaria inscripción, una serenidad, una armonía que en vida ninguno de los dos pudieron gozar. ¿Es necesario suprimir la alteridad, eliminar la misma posibilidad de la diferencia, y con ella, la misma identidad del sujeto? ¿Es necesario, en vista del fracaso de una convivencia fundada sobre los ejes cartesianos de la conciencia moderna, renunciar al proyecto ilustrado, a un mundo de seres humanos libres? Braudillard sugiere que ya de hecho se ha producido tal claudicación.

Teoría del cuerpo clónico (Braudillard)

Tal vez era todavia mejor el infierno de los demás que volver a esta forma original de intercambio imposible. La transparencia del mal, Jean Braudillard

La obsesión del Otro, el Otro que soy Yo sin serlo, ha perseguido al pensamiento occidental hasta los tiempos en que nos hallamos. La historia del cuerpo no se puede trazar sin acudir al recuento de sus metamorfosis, a esa continua relación que mantiene la mirada con su reflejo más allá de sí, en el Doble, en la multiplicidad de las formas miméticas y mutantes, en sus juguetonas metamorfosis. El reconocimiento de la propia identidad requiere el esfuerzo de soportar el hecho monstruoso de no ser en realidad uno mismo, de verse de pronto transformado en una bestia, en una rana, en una niña que mengua y crece de forma alarmante, en un escarabajo, $o$ en una pantera. Cada cual no deja de soñar sus metamorfosis y, tras el sueño, las fantásticas mutaciones cobran nebulosa forma en los mitos y en los cuentos de hadas. El hombre no puede dejar de imaginarse siempre convertido en otra cosa. Su identidad radica en la fugitiva danza de las máscaras. «El grito del reconocimiento: Iste ego sum!, que Narciso profiere -dice José Jiménez-, ilumina lo 
inestable de nuestra identidad, nos reflejamos en la imagen: somos y no somos" ${ }^{22}$.

Pero, ¿acaso no nos llevaba este juego de máscaras y de miradas al estado agónico del que quiere y no puede? ¿Y no ha pretendido romper el hombre actual la maquinaria de la ficción, aún a riesgo de condenarse con ello a no saber nunca más de sí? Según Braudillard, cuya obra La transparencia del mal ${ }^{23}$ ocupará nuestra atención en este capítulo final, correspondía a nuestra época demoler la relación fundamental y fabulosa del Uno con lo Otro, materializarla en carne $y$ hueso de forma tal que la imagen deseada ya no fuera nunca más tan voluble y huidiza como el reflejo de un rostro en el agua, sino precisa y determinada, verdadera copia fiel de un original infinitamente duplicado. Reproducción de lo Mismo. La estrategia para eludir el infierno del Otro que nuestra época ha sido capaz de idear consiste, pues, en suprimir las diferencias, en proponer un ser humano que se repite por simple repetición clónica. «Ni hijo, ni gemelo, ni reflejo narcisista, el clon es la materialización del doble por vía genética, es decir, la abolición de cualquier alteridad y de cualquier imaginario ${ }^{24}$.

No está provocada la clonación por una pulsión de muerte que llevase al ser humano al autoexterminio mediante la conversión de su humana diversidad en uniformidad vegetal, monocelular, protozooaria; tampoco se trata de satisfacer el delirio de engendrarse a sí mismo, pues en la clonación celular desaparece cualquier rastro de sexualidad y parentesco; ni siquiera se puede ver en el clónico el exceso de una subjetividad vanidosa que

22 JIMÉNEZ. J., Cuerpo y tiempo. La imagen de las metamorfosis, Barcelona, Destino, 1993, pg. 32. En este libro, además de un buen recorrido por la literatura clásica griega y latina sobre transformaciones, podemos encontrar un breve pero sugerente acercamiento a la relación entre el cuerpo, la identidad y la ficción en la imaginación contemporánea.

${ }^{23}$ BRAUDILLARD, J., La transparencia del mal. Ensayo sobre los fenómenos extremos, Barcelona, Anagrama, 1991.

${ }^{24}$ Ibid., pg. 126. 
buscase la repetición de sus gracias. La clonación persigue en realidad la destrucción absoluta de la posibilidad del Otro y, al unísono, también la desaparición de esa totalidad denominada cuerpo. Porque si es posible reproducir la estructura corporal entera a partir únicamente de una célula, entonces el conjunto ya no tiene valor propio ni agrega nada a lo que en forma genética se halla resumido desde el primer momento en el interior del núcleo celular. El cuerpo se destaca entonces como una mera prótesis, un artefacto que ha surgido extendiéndose a partir de una cantidad matricial de información que prolifera de modo uniforme y mecánico. Cada uno de los individuos no es más que «una metástasis cancerosa de su fórmula de base» ${ }^{25}$.

Con esto, todas las formas de relación del individuo hacia el Otro desaparecen; el sujeto se encierra en su propios procesos psicotrópicos, queda absorbido por la percepción de sus estados neurovegetativos. Braudillard lo ejemplifica con la imagen del cuerpo del drogadicto: es un cuerpo observado desde dentro, sin imagen más allá de él, sin discurso; cuerpo silencioso, mental, de mirada vacía, inmanente, sin puesta en escena, entregado a sus procesos endocrinos, de una plasticidad táctil, de imagen absolutamente perdida, sin representación posible, ni para los demás, ni para sí mismos, "cuerpos definitivamente alejados de su resurrección»".

Se diría entonces que, suprimido el Otro, sólo resta la interminable repetición de lo Mismo, la confrontación del individuo frente a sí en la vacuidad enorme y monstruosa de un cuerpo sin reflejo. «Nosotros ya no practicamos el incesto, pero lo hemos generalizado en todas sus derivaciones. La diferencia consiste en que nuestro incesto ya no es sexual ni familiar, sería más bien escisiparo y protozoario. Así es como hemos burlado la prohibición: con la subdivisión de lo Mismo, con la copulación de lo Mismo con lo Mismo, sin pasar por el Otro" ${ }^{27}$.

\footnotetext{
25 Ibid., pg. 129.

26 Ibid., pg. 130-131.

NOTAS Y COMENTARIOS

27 lbid., pg. 131.
} 
A estas alturas de la escena el ladrón ha triunfado plenamente porque al cabo logró encerrar a los protagonistas en sus cuerpos. El cadáver que se pasea por la escena es el cadáver del Otro, y si al ladrón le dejasen se lo comería. Y una vez que se ha producido este asesinato, ya sólo queda fingir que el Otro existe, aceptar su muerte y aceptar tejer la fábula de su ficticia vida. Nuestra cultura produce cientos de miles de formas de constatar la existencia de un Otro cadáver, «casi un mercado negro de la alteridad y la diferencia ${ }^{28}$.

La consecuencia del asesinato no es únicamente la desaparición del Otro, y la orgía de comprensión política, psicológica, sociológica de una alteridad ya muerta y que cobra el cuerpo falso y repulsivo de los conceptos hueros (la Sociedad, la Naturaleza, el Hombre del la Calle, los Hombres de Color, los Indios Amenazados, los Niños, los Ancianos, los Parados, etc...), sino la misma desaparición del sujeto, que ya no es nada, porque tiene su correlato en nadie. No es el otro de nadie. No sólo ha desaparecido lo social, sino también lo individual, porque el individuo no podía sobrevivir en la cárcel de su cuerpo hermético, esto es, en un mundo en el que cuando mira no deja de mirarse a sí mismo. Aquella alteridad del Otro violenta, irrebasable, conflictiva, ha sido substituida por su simulación, la diferencia, mucho más domesticable, que supone por una parte la hipócrita demostración de reconocimiento y aceptación de lo diferente, y por otra, la discriminación que lo aisla y lo niega. El ladrón ha convertido el drama en mascarada: «El amo de los símbolos universales de la alteridad y la diferencia es el amo del mundo. El que piensa la diferencia es antropológicamente superior (sin duda, ya que él es quien inventa la antropología). Tiene todos los derechos, ya que él es quien los inventa. El que no piensa la diferencia, el que no juega el juego de la diferencia, debe ser exterminado» ${ }^{29}$.

\footnotetext{
28 Ibid., pg. 134.

29 Ibid., pg. 143.
} 